Jurnal Ilmu-Ilmu Peternakan 26(3): 27 - 37

ISSN : 0852-3681

E-ISSN : 2443-0765

CFakultas Peternakan UB, http://jiip.ub.ac.id/

\title{
Penampilan produksi ayam pedaging yang dipelihara pada lantai atas dan lantai bawah
}

\author{
R. Dharmawan, H. S. Prayogi, dan V. M. A. Nurgiartiningsih \\ Fakultas Peternakan Universitas Brawijaya, Malang \\ Jl. Veteran Malang 65145 Jawa Timur \\ career.rachmadrmwn@gmail.com
}

\begin{abstract}
This research aimed to study the performance of broiler raised in 3 stair floors. This research had been done from 09 September to 12 Oktober 2016 at Purwosari, Pasuruan. The data of performance was obtained from a poultry house which divided into 3 floors. The brooding period was given for 2 weeks in $2^{\text {nd }}$ floor, on $15^{\text {th }}$ days the chicken were separated into $1^{\text {st }}$ and $3^{\text {rd }}$ floor with the same house density. The obtained data was analyzed using T-test (independent samples T-test) to see the difference in between. The result of this research showed that there were highly significant differences on body weight gain, slaughter weight, and feed conversion ratio of broiler between $1^{\text {st }}$ and $3^{\text {rd }}$ floor. However, the differences floor did not contribute to differences on feed consumption ( $2.357 \mathrm{~g} /$ bird on $1^{\text {st }}$ floor and $2.351 \mathrm{~g} /$ bird on $3^{\text {rd }}$ floor $)$. The body weight gain of broiler at $1^{\text {st }}$ floor $(1.293 \pm 96.52 \mathrm{~g} / \mathrm{bird})$ was lower than $3^{\text {rd }}$ floor $(1.331 \pm 82.77 \mathrm{~g} / \mathrm{bird})$. The final weight of broiler at $1^{\text {st }}$ floor $(1.780 \pm 90.6 \mathrm{~g} / \mathrm{bird})$ was lower than $3^{\text {rd }}$ floor $(1.818 \pm 81.8 \mathrm{~g} /$ bird $)$. Feed conversion ratio of broiler at $1^{\text {st }}$ floor $(1.83 \pm 0.14)$ was higher than $3^{\text {rd }}$ floor $(1.77 \pm 0.11)$. The conclusion of this research was that the performance of broiler raising at 3rd floor has better performance than those at $1^{\text {st }}$ floor. It is suggested to further research to determine the best production performance of broilers reared on the $1^{\text {st }}$ floor, $2^{\text {nd }}$ floor and $3^{\text {rd }}$ floor.
\end{abstract}

Keywords: depletion, microclimate, stair floors

\section{PENDAHULUAN}

Kandang merupakan bangunan yang digunakan sebagai tempat tinggal ternak yang memiliki fungsi primer dan fungsi sekunder. Fungsi primer kandang berarti kandang sebagai tempat tinggal ternak yang dapat melindungi ternak dari pengaruh buruk cuaca, iklim dan gangguan binatang buas. Fungsi sekunder kandang berarti kandang sebagai tempat peternak bekerja untuk menjalankan kegiatan pemeliharaan ternak. Sarjana (2007) menjelaskan secara umum tipe kandang yang digunakan pada pemeliharaan ayam pedaging di
Indonesia ada dua macam, yaitu kandang terbuka (open sided house) dan kandang tertutup (closed house). Jenis kandang di atas dapat dikombinasikan dengan beberapa tipe atap dan lantai yang berbeda pula. Perkandangan dengan tipe atap monitor menjadikan suhu udara lebih lancar dan membantu mengeluarkan debu dan amonia dari dalam kandang. Sedangkan tipe lantai yang umum digunakan pada pemeliharaan ayam pedaging adalah slat, litter, dan kombinasi keduanya.

Pattiselano dan Randa (2005), menyatakan bahwa kandang termasuk 
peralatannya merupakan salah satu sarana fundamental yang secara langsung turut serta menentukan sukses tidaknya suatu usaha peternakan. Kondisi kandang harus diperhatikan dengan baik yang mengacu pada prinsip ideal yang senantiasa memberi perhatian pada temperatur lingkungan, kelembaban udara dan sirkulasi atau pertukaran udara. Kualitas udara yang dibutuhkan oleh ternak unggas adalah kadar oksigen $\quad(>19,6 \%)$, karbondioksida $\quad(<0,35 \%)$, karbonmonoksida ( $<10 \mathrm{ppm}$ ), amonia $(<10 \quad$ ppm), dan rekomendasi kelembaban udara 65-75\%.

Kandang panggung yang digunakan salahsatu peternak kemitraan di Kecamatan Purwosari dimodifikasi menjadi 3 lantai. Masa brooding (selama 14 hari) dilakukan di lantai 2 dan masa pembesaran (selama 19 hari) dilakukan pada lantai 1 dan lantai 3. Modifikasi kandang yang dilakukan peternak bertujuan untuk meningkatkan efisiensi penggunaan lahan yang terbatas, sedangkan masa pembesaran hanya menggunakan lantai 1 dan lantai 3 bertujuan memberikan sirkulasi udara yang optimal sehingga meminimalkan resiko kematian yang diakibatkan oleh stres pada ternak. Pemeliharaan pada lantai 1 dan lantai 3 tersebut mengakibatkan adanya perbedaan suhu udara, kelembaban, dan sirkulasi udara sehingga dapat mempengaruhi penampilan produksi ayam pedaging. Dengan memperhatikan adanya pembagian populasi pada lantai 1 dan lantai 3, maka informasi mengenai kelebihan dan kekurangan dari masing-masing lantai tersebut sangat diperlukan. Hal ini disebabkan karena pada masing-masing lantai dapat mempengaruhi kenyamanan ternak ayam pedaging yang dipelihara. Penelitian ini bertujuan untuk mengetahui penampilan produksi ayam pedaging yang dipelihara pada lantai atas dan lantai bawah.

\section{MATERI DAN METODE}

Penelitian ini dilaksanakan di peternak kemitraan Indahnya Maju Bersama (IMB) Desa Tejowangi, Kecamatan Purwosari, Kabupaten Pasuruan pada bulan September sampai dengan Oktober 2016.

Materi yang digunakan dalam penelitian ini adalah ayam pedaging strain Cobb. Model kandang yang digunakan dalam penelitian ini adalah open sided house berbentuk panggung tiga lantai dengan populasi 6000 ekor/kandang pada awal pemeliharaan. Populasi pada umur 15 hari dibagi sama besar dan dipelihara pada lantai 1 dan lantai 3. Kandang open sided house ini memiliki ukuran panjang 49 meter dan lebar 8 meter. Model atap yang digunakan adalah tipe monitor. Alas yang digunakan ketika masa brooding di lantai 2 adalah sekam. Slat yang digunakan pada masa pembesaran terbuat dari bilah bambu dengan ukuran celah \pm 2 $\mathrm{cm}^{2}$.

Metode yang digunakan dalam penelitian ini adalah metode percobaan, yaitu dengan membagi ayam pedaging menjadi 2 kelompok pada lantai 1 dan lantai 3. Kepadatan kandang yang digunakan adalah 7-8 ekor $/ \mathrm{m}^{2}$. Populasi di lantai 2 dengan nilai koefisien keragaman $<10 \%$ sebelum dipindahkan pada lantai 1 dan 3. Masa brooding dilakukan di lantai 2 selama 14 hari, dilanjutkan dengan masa pembesaran yang dilakukan di lantai 1 dan 3 dengan membagi populasi menjadi 2 kelompok. Pengambilan data dilakukan secara random sampling sebanyak 5\% populasi yaitu 150 ekor/lantai. Penampilan produksi ayam pedaging yang dipelihara pada kandang panggung di lantai bawah (lantai 1) akan dibandingkan dengan penampilan produksi ayam pedaging 
yang dipelihara di lantai atas (lantai 3) yang dipanen pada umur 33 hari.

Pengamatan unsur iklim mikro didalam kandang (suhu udara, kelembaban, dan kecepatan angin) dilakukan 4 kali sehari yaitu pada 02.00, 07.00, 13.00, 17.00 WIB. Pengukuran suhu udara, kelembaban, dan kecepatan angin dilakukan pada 1/3 dan 2/3 panjang kandang dengan menggunakan kestrel. Pengukuran unsur iklim mikro didalam kandang dilakukan pada ketinggian \pm 50 cm dari permukaan lantai kandang. Hal ini dilakukan dengan mempertimbangkan postur tinggi ayam sehingga diperoleh kondisi yang dirasakan oleh ayam pedaging.
Data yang diperoleh dianalisis menggunakan uji-t untuk mengetahui perbedaan penampilan produksi pemeliharaan ayam pedaging di lantai 1 dan di lantai 3 pada kandang panggung tiga lantai. Data rataan unsur iklim mikro didalam kandang dianalisis menggunakan uji-t untuk mengetahui perbedaan suhu udara, kelembaban udara, dan kecepatan angin pada lantai 1 dan lantai 3.

\section{HASIL DAN PEMBAHASAN}

\section{Unsur iklim mikro didalam kandang}

Hasil pengamatan suhu udara didalam kandang panggung tiga lantai disajikan pada Tabel 1.

Tabel 1. Rataan suhu udara di dalam kandang panggung tiga lantai

\begin{tabular}{|c|c|c|c|c|c|}
\hline \multirow{2}{*}{ Lantai } & \multicolumn{4}{|c|}{ Suhu Udara $\left({ }^{\circ} \mathrm{C}\right)$} & \multirow{2}{*}{ Rata-rata } \\
\hline & 02.00 & 07.00 & 13.00 & 17.00 & \\
\hline 1 & 24,5 & 27,0 & 29,9 & 28,4 & $27,5 \pm 0,59^{\mathrm{a}}$ \\
\hline 3 & 23,9 & 25,7 & 28,5 & 26,1 & $26,0 \pm 1,22^{b}$ \\
\hline
\end{tabular}

Keterangan : ${ }^{\mathrm{a}-\mathrm{b}}$ Superskrip yang berbeda pada kolom yang sama menunjukkan perbedaan yang sangat nyata $(\mathrm{P}<0,01)$

Hasil pengamatan menunjukkan bahwa rataan suhu udara di lantai 1 $\left(27,5 \pm 0,59 \quad{ }^{\circ} \mathrm{C}\right) \quad$ lebih tinggi dibandingkan dengan suhu udara di lantai $3\left(26,0 \pm 1,22{ }^{\circ} \mathrm{C}\right)$. Berdasarkan hasil uji-t menunjukkan bahwa suhu udara berbeda sangat nyata $(\mathrm{P}<0,01)$ antara lantai 1 dan lantai 3. Suhu udara didalam kandang disebabkan oleh beberapa sumber panas, yaitu: 1) panas dari tubuh ternak 2) fermentasi litter, dan 3) sinar matahari. Ternak selalu melakukan metabolisme untuk memenuhi kebutuhan hidupnya yang salah satu hasilnya adalah panas tubuh, panas dari tubuh ternak dapat menyebar secara radiasi terhadap suhu lingkungan. Fermentasi litter pada kandang panggung tiga lantai terjadi di lantai dasar dan lantai 2. Salah satu hasil fermentasi litter adalah panas. Jarak antara lantai dasar dan lantai 1 adalah \pm 1 meter sedangkan jarak antara lantai 2 dan lantai 3 adalah \pm 2 meter. Jarak antara lantai 1 dengan lantai dasar yang rendah mengakibatkan perpindahan panas menjadi lebih cepat sehingga kenaikan suhu udara di lantai 1 lebih tinggi dibandingkan dengan suhu udara di lantai 3. Posisi kandang yang digunakan pada saat penelitian adalah membujur dari timur ke barat. Menurut Leeson and Summers (2000), posisi kandang yang membujur dari timur ke barat dapat menurunkan pengaruh dari sinar matahari langsung kedalam kandang. Posisi kandang tersebut dapat mengurangi suhu udara didalam 
kandang. Pengukuran unsur iklim mikro di dalam kandang dilakukan pada 4 waktu yaitu pukul 02.00 (terjadinya suhu terendah), 07.00, 13.00 (terjadinya suhu tertinggi), dan 17.00 sebagai faktor yang mempengaruhi kenyamanan ternak. Rasa nyaman (comfortable) ternak dalam kandang dipengaruhi oleh beberapa faktor, seperti suhu, kelembaban, tingkat kepadatan ternak dan jenis lantai kandang yang dipergunakan (Umam, dkk. 2015). Tingginya suhu udara lingkungan merupakan salah satu masalah dalam pencapaian performa ayam pedaging yang optimal. Ayam pedaging akan mengalami stress pada suhu udara yang tinggi, yang akan mempengaruhi penurunan konsumsi pakan sehingga terjadi penurunan bobot tubuh (Nova, 2008). Menurut Kusnadi (2006), ayam pedaging termasuk hewan homeothermis dengan suhu nyaman $24{ }^{\circ} \mathrm{C}$ yang akan berusaha mempertahankan suhu tubuhnya dalam keadaan relatif konstan antara lain melalui peningkatan frekuensi pernafasan dan jumlah konsumsi air minum serta penurunan konsumsi pakan.

Hasil pengamatan kelembaban udara didalam kandang panggung tiga lantai disajikan pada Tabel 2.

Tabel 2. Rataan kelembaban udara di dalam kandang panggung tiga lantai

\begin{tabular}{|c|c|c|c|c|c|}
\hline \multirow{2}{*}{ Lantai } & \multicolumn{4}{|c|}{ Kelembaban Udara (\%) } & \multirow{2}{*}{ Rata-rata } \\
\hline & 02.00 & 07.00 & 13.00 & 17.00 & \\
\hline 1 & 71,9 & 71,6 & 82,0 & 77,9 & $75,9 \pm 2,96^{\mathrm{a}}$ \\
\hline 3 & 69,4 & 71,9 & 79,7 & 73,2 & $73,6 \pm 2,95^{b}$ \\
\hline
\end{tabular}

Keterangan : ${ }^{\mathrm{a}-\mathrm{b}}$ Superskrip yang berbeda pada kolom yang sama menunjukkan perbedaan yang nyata $(\mathrm{P}<0,05)$

Rataan kelembaban udara di lantai $1 \quad(75,9 \pm 2,96 \%)$ lebih tinggi dibandingkan kelembaban udara di lantai 3 (73,6 $\pm 2,95 \%)$. Hasil uji-t menunjukkan bahwa kelembaban udara berbeda nyata $(\mathrm{P}<0,05)$ antara lantai 1 dan lantai 3. Kelembaban udara umumnya memiliki korelasi yang berbanding terbalik dengan suhu udara, namun beberapa faktor dapat menyebabkan kelembaban udara menjadi berbanding lurus dengan suhu udara. Kelembaban udara didalam kandang dipengaruhi oleh: 1) respirasi ternak, 2) air minum, dan 3) kotoran ternak. Kelembaban yang tinggi pada lantai 1 dipengaruhi oleh respirasi ternak yang meningkat untuk menstabilkan suhu tubuh dari suhu lingkungan yang tinggi. Ayam yang mengalami cekaman panas, jalur utama untuk menjaga keseimbangan suhu adalah pelepasan panas tubuh melalui salu- ran pernapasan (Sugito, 2008). Suhu lingkungan yang tinggi pada lantai 1 juga berpengaruh menguapkan air yang terdapat pada tempat air minum ternak. Suhu yang tinggi pada lantai 1 berakibat ternak cenderung mengkonsumsi air minum berlebih sehingga eskreta menjadi lebih lembek. Jarak antara feses dan ternak pada lantai 1 lebih rendah dibandingkan dengan lantai 3 dengan lantai 2 sehingga meningkatkan persentase kelembaban udara di lantai 1. Menurut Nadzir dkk. (2015), ketinggian lantai kandang dari tanah juga akan berpengaruh terhadap ayam yang ada didalam kandang. Apabila terlalu rendah, uap dari kotoran ayam akan terhirup kembali oleh ayam sehingga akan berdampak terhadap kesehatan ternak. Tingkat kelembaban udara berpengaruh nyata pada tingkat pelepasan panas terutama saat suhu tubuh ternak tinggi (Nuriyasa, dkk. 
2010). Selain mengakibatkan cekaman panas, suhu dan kelembaban yang tinggi dapat menyebabkan perilaku agresif semakin meningkat. Gas metan dan amonia yang dapat meningkatkan suhu udara dalam kandang sehingga dapat menyebabkan perubahan tingkah laku yaitu timbulnya sifat agresif (Puspani, dkk. 2008).

Hasil pengamatan kecepatan angin di dalam kandang panggung tiga lantai disajikan pada Tabel 3.

Tabel 3. Rataan kecepatan angin di dalam kandang panggung tiga lantai

\begin{tabular}{|c|c|c|c|c|c|}
\hline \multirow{2}{*}{ Lantai } & \multicolumn{4}{|c|}{ Kecepatan angin (m/dt) } & \multirow{2}{*}{ Rata-rata } \\
\hline & 02.00 & 07.00 & 13.00 & 17.00 & \\
\hline 1 & 0,216 & 0,063 & 0,089 & 0,079 & $0,1 \pm 0,06^{\mathrm{a}}$ \\
\hline 3 & 0,332 & 0,111 & 0,163 & 0,111 & $0,2 \pm 0,07^{\mathrm{b}}$ \\
\hline
\end{tabular}

Keterangan : ${ }^{\mathrm{a}-\mathrm{b}}$ Superskrip yang berbeda pada kolom yang sama menunjukkan perbedaan yang sangat nyata $(\mathrm{P}<0,01)$

Rataan kecepatan angin di lantai $1(0,1 \pm 0,06 \mathrm{~m} / \mathrm{dt})$ lebih rendah dibandingkan dengan kecepatan angin di lantai $3(0,2 \pm 0,07 \mathrm{~m} / \mathrm{dt})$. Hasil Uji-t menunjukkan bahwa kecepatan angin berbeda sangat nyata $(\mathrm{P}<0,01)$ antara lantai 1 dan lantai 3. Rataan sirkulasi udara di lantai 1 lebih rendah karena angin mengalir hanya melalui samping kandang dan bawah kandang, sedangkan pada lantai 3 sirkulasi udara mengalir lebih lancar dari samping kandang, bawah kandang, dan melalui atap kandang. Rataan suhu udara pada saat penelitian masih dapat ditolerir oleh ayam pedaging, dijelaskan Yunike dkk. (2011) bahwa keuntungan lain dari penggunaan kandang panggung adalah sirkulasi udara sangat lancar, udara segar juga mudah masuk melalui lantai kandang yang bercelah selain dapat masuk juga melalui dinding kandang. Sirkulasi udara yang lancar menyebabkan suhu udara didalam kandang masih nyaman yaitu rata-rata $26,39{ }^{\circ} \mathrm{C}$, suhu tersebut masih bisa ditolerir oleh ayam meskipun kepadatan kandangnya berbedabeda. Atap kandang dengan sistem monitor sangat membantu sirkulasi udara didalam kandang, karena udara kotor dari dalam kandang langsung keluar melalui celah atap, sedangkan udara panas dari atas kandang tidak langsung masuk ke kandang; karena atap kandang terdiri atas dua lapis yang di antara atapnya terdapat celah untuk meredam udara panas. Faktor-faktor yang mempengaruhi kecepatan angin adalah konstruksi kandang dan tata letak kandang. Kandang panggung memiliki sirkulasi udara yang baik apabila dibandingkan dengan kandang postal. Kandang yang berjarak terlalu dekat dengan pohon besar berdaun rimbun dapat mengurangi bau amonia akan tetapi menurunkan kecepatan angin. Pohon-pohon tersebut dapat berperan sebagai pemecah angin sehingga kecepatan angin menuju kandang menjadi semakin kecil. Sirkulasi udara menjadi sangat penting untuk meratakan udara segar kedalam kandang sehingga suhu udara dalam kandang menjadi stabil sesuai kebutuhan ayam (Olivia, dkk. 2015).

\section{Penampilan produksi ayam pedaging yang dipelihara pada kandang panggung tiga lantai}

Rataan dan simpangan baku konsumsi pakan, Bobot Badan (BB), dan Feed Conversion Ratio (FCR) disajikan pada Tabel 4. Hasil penelitian dianalisis dengan uji-t yang menunjukkan bahwa antara lantai 1 dan 
lantai 3 tidak berbeda nyata terhadap konsumsi pakan dan berbeda sangat nyata $(\mathrm{P}<0,01)$ terhadap pertambahan bobot badan (PBB), dan feed conversion

Ratio (FCR).

Tabel 4. Rataan dan simpangan baku konsumsi pakan, bobot badan, dan FCR

\begin{tabular}{|c|c|c|c|c|c|c|}
\hline \multirow{2}{*}{$\begin{array}{l}\text { Umur } \\
\text { (hari) }\end{array}$} & \multicolumn{2}{|c|}{$\begin{array}{c}\text { Konsumsi Pakan } \\
\text { (g/ekor) }\end{array}$} & \multicolumn{2}{|c|}{ Bobot Badan (g/ekor) } & \multicolumn{2}{|c|}{ Feed Conversion Ratio } \\
\hline & Lantai 1 & Lantai 3 & Lantai 1 & Lantai 3 & Lantai 1 & Lantai 3 \\
\hline 7 & \multicolumn{2}{|c|}{$174 \pm 0,4^{\mathrm{a}}$} & \multicolumn{2}{|c|}{$180 \pm 9,7^{\mathrm{a}}$} & \multicolumn{2}{|c|}{$1,03 \pm 0,04^{\mathrm{a}}$} \\
\hline 14 & \multicolumn{2}{|c|}{$590 \pm 1,1^{\mathrm{a}}$} & $487 \pm 23,1^{a}$ & $488 \pm 21,8^{\mathrm{a}}$ & \multicolumn{2}{|c|}{$1,21 \pm 0,05^{\mathrm{a}}$} \\
\hline 21 & $\begin{array}{c}769,13 \pm 3 \\
9^{\mathrm{a}}\end{array}$ & $\begin{array}{c}770,81 \pm 2 \\
9^{\mathrm{a}}\end{array}$ & $925 \pm 50,2^{\mathrm{a}}$ & $945 \pm 53,0^{b}$ & - & - \\
\hline 28 & $\begin{array}{c}867,69 \pm 6, \\
1^{\mathrm{a}}\end{array}$ & $\begin{array}{c}863,86 \pm 4 \\
7^{\mathrm{a}}\end{array}$ & $1475 \pm 53,8^{a}$ & $1505 \pm 53,2^{b}$ & - & - \\
\hline 33 & $\begin{array}{c}719,69 \pm 2 \\
2^{\mathrm{a}}\end{array}$ & $\begin{array}{c}716,55 \pm 2 \\
9^{\text {a }} \\
\end{array}$ & $1780 \pm 90,6^{\mathrm{a}}$ & $1818 \pm 81,8^{b}$ & $\begin{array}{c}1,83 \pm 0,1 \\
4^{\mathrm{a}}\end{array}$ & $1,77 \pm 0,11^{b}$ \\
\hline
\end{tabular}

Keterangan : ${ }^{\mathrm{a}-\mathrm{b}}$ Superskrip yang berbeda pada baris yang sama menunjukkan perbedaan yang sangat nyata $(\mathrm{P}<0,01)$

\section{Konsumsi pakan ayam pedaging yang dipelihara pada lantai 1 dan 3}

Konsumsi pakan selama masa pembesaran (umur 15 hari hingga 33 hari) pada lantai 1 adalah 2.357 g/ekor, sedangkan pada lantai 3 adalah 2.351 g/ekor. Konsumsi pakan pada lantai 1 lebih tinggi 6 g/ekor daripada konsumsi pakan pada lantai 3. Hasil uji-t menunjukkan bahwa konsumsi pakan ayam pedaging berbeda tidak nyata antara lantai 1 dan lantai 3. Menurut Nadzir dkk. (2015), untuk mencapai pertumbuhan yang optimal usaha yang diperlukan diantaranya dengan pemberian makanan yang bernutrisi tinggi, perbaikan manajemen dengan pemberian temperatur lingkungan pemeliharaan (kandang) yang optimal.

Konsumsi pakan dipengaruhi oleh temperatur lingkungan, kesehatan ayam, perkandangan, wadah pakan, kandungan zat makanan dalam pakan dan stres yang terjadi pada ternak unggas tersebut (Faiq, dkk. 2013). Kisaran suhu udara lingkungan yang nyaman bagi ayam untuk hidup berkisar antara $18-22{ }^{\circ} \mathrm{C}$. Tingginya suhu udara ling- kungan merupakan salah satu masalah dalam pencapaian performa ayam pedaging yang optimal. Ayam pedaging akan mengalami stres pada suhu udara yang tinggi, yang akan mempengaruhi penurunan konsumsi pakan sehingga terjadi penurunan bobot tubuh (Nova, 2008). Ayam akan berusaha mempertahankan suhu tubuhnya dalam keadaan relatif konstan antara lain melalui peningkatan pernafasan dan konsumsi air minum serta penurunan konsumsi pakan sehingga akan terjadi penurunan dalam pertumbuhan dan produksi / produktivitas. Pada daerah tropis, penguapan air dari tubuh ayam merupakan aktivitas yang sangat penting melalui pernafasan dan kotorannya (Pattiselano dan Randa, 2005). Menurut Suarjaya dan Nuriyasa (2010), untuk mendapatkan produksi yang baik perlu diadakan kontrol dengan penimbangan yang teratur setiap minggunya. Apabila berat ayam belum memenuhi standar, maka jumlah pakan dapat ditambah dengan prosentase kekurangan berat badan dari standar. Akan tetapi bila bobot badan ayam telah melebihi standar, maka jumlah pakan 
yang diberikan tetap sama dengan jumlah pakan yang diberikan sebelumnya.

\section{Pertambahan bobot badan (pbb) ayam pedaging yang dipelihara pada lantai 1 dan 3}

Hasil penelitian menunjukkan bahwa rataan pertambahan bobot badan selama masa pembesaran (umur 15 hari hingga 33 hari) pada lantai 1 adalah 1.292,89 $\pm 96,52$ g/ekor, sedangkan pada lantai 3 adalah 1.330,82 $\pm 82,77$ g/ekor. Hal tersebut berarti bahwa terdapat selisih rataan pertambahan bobot badan sebesar 37,93 g/ekor. Hasil uji-t menunjukkan bahwa pertambahan bobot badan ayam pedaging berbeda sangat nyata $(\mathrm{P}<0,01)$ antara lantai 1 dan lantai 3. Ayam pedaging mengkonsumsi pakan bertujuan untuk mencukupi kebutuhan hidup pokok dan produksi. Pertumbuhan merupakan manifestasi dari perubahan-perubahan yang terjadi dalam sel yang mengalami prosesproses pertambahan jumlah sel yang selanjutnya diikuti dengan proses pembesaran ukuran sel (Suarjaya dan Nuriyasa, 2010).

Pertumbuhan bobot badan dipengaruhi oleh beberapa faktor yaitu tipe ayam, jenis kelamin, galur, tata laksana, temperatur lingkungan, tempat ayam dipelihara, kualitas dan kuantitas pakan (Ramadhani, dkk. 2016). Kisaran suhu udara lingkungan yang nyaman bagi ayam untuk hidup berkisar antara $18-22{ }^{\circ} \mathrm{C}$. Tingginya suhu udara lingkungan merupakan salah satu masalah dalam pencapaian performa ayam pedaging yang optimal. Ayam pedaging yang diberikan pakan dalam jumlah banyak, tidak berarti akan mencapai pertambahan bobot badan yang tinggi pula (Amrullah, 2003). Menurut Indarto (1999), pertambahan bobot badan ayam berlangsung sesuai dengan kondisi fisiologis ayam, yaitu bobot badan ayam akan berubah kearah bobot badan dewasa. Pertumbuhan akan berangsur meningkat dan akan terhenti pada periode tertentu. Pertumbuhan ayam pedaging yang paling cepat terjadi sejak menetas sampai umur 4-6 minggu, kemudian mengalami penurunan dan terhenti sampai mencapai dewasa (Kusnadi, dkk. 2006). Salah satu kriteria untuk mengukur pertambahan bobot badan adalah dengan mengukur kenaikan bobot badan yang dicapai oleh seekor ternak selama periode tertentu. Dalam pemeliharaan ayam pedaging pertambahan bobot badan setiap ayam perlu diperhatikan. Hal ini dikarenakan agar produksi ayam saat pemanenan dapat stabil dan baik.

Hasil analisis data menunjukkan adanya perbedaan yang sangat nyata $(\mathrm{P}<0,01)$ terhadap pertambahan bobot badan. Rataan pertambahan bobot badan di lantai 1 lebih rendah dibandingkan dengan pertambahan bobot badan di lantai 3. Hal tersebut menunjukkan bahwa pertambahan bobot badan di lantai 3 lebih baik dibandingkan pertambahan bobot badan di lantai 1.

\section{Bobot akhir ayam pedaging yang di- pelihara pada lantai 1 dan 3}

Hasil penelitian menunjukkan bahwa rataan bobot akhir selama masa pemeliharaan 33 hari pada lantai 1 adalah 1.780,11 $\pm 90,6$ g/ekor, sedangkan pada lantai 3 adalah 1.818,04 $\pm 81,8$ g/ekor. Hal tersebut berarti bahwa terdapat selisih rataan bobot akhir sebesar 37,927 g/ekor. Hasil uji-t menunjukkan bahwa bobot akhir ayam pedaging berbeda sangat nyata $(\mathrm{P}<0,01)$ antara lantai 1 dan lantai 3. Perbedaan yang sangat nyata tersebut dipengaruhi karena unsur iklim mikro pada lantai 1 kurang baik dibandingkan dengan lantai 3, karena dengan tingginya suhu membuat ayam akan cenderung 
beraktivitas lebih, sehingga durasi istirahat menjadi lebih sedikit. Hal ini berdampak pada rendahnya persentase pembentukan lemak abdominal. Pembentukan lemak abdominal sangat mempengaruhi bobot panen ayam pedaging yang dipelihara (Sulistyoningsih, dkk. 2012).

Usaha peternakan tidak akan terlepas dari tahap pemilihan bibit, manajemen pemeliharaan, perkandangan dan vaksinasi. Kesehatan ternak merupakan bagian integral dari usaha peningkatan produksi ternak. Produktifitas dan reproduktifitas hanya dapat dicapai secara optimal jika ternak dipelihara dalam keadaan sehat sehingga pertambahan bobot badan akan menjadi optimal dengan mortalitas yang rendah (Risnajati, 2012). Penggunaan kandang panggung memiliki resiko kecelakaan pada ayam yang lebih besar dibandingkan dengan kandang postal. Menurut North and bell (2004), kebaikan kandang sistem panggung adalah kandang yang selalu bersih karena kotorannya jatuh ke tempat penampungan, peredaran udara lebih lancar, dapat menampung ayam lebih banyak, pengontrolan penyakit lebih mudah, menurunkan resiko timbulnya penyakit coccidiosis serta konversi pakan lebih baik. Salah satu faktor yang mempengaruhi besar kecilnya bobot akhir ayam pedaging adalah konsumsi pakan dan terpenuhinya kebutuhan zat makanan ayam pedaging, maka konsumsi pakan seharusnya memiliki korelasi positif dengan bobot badan (Negoro, dkk. 2013). Peternak kemitraan Indahnya Maju Bersama memiliki standar rata-rata bobot akhir 1.800 g/ekor. Menurut Risnajati (2012), rataan bobot karkas tertinggi diperoleh dari strain Cobb sebesar 1.363 g, diikuti strain Hubbard sebesar 1.348 g. Meskipun bobot akhir strain Hubbard (1.976 g) lebih tinggi dari strain Cobb (1.970 g).
Bidura dan Suasta (2006) menyatakan bahwa hormon pertumbuhan yang disekresikan oleh pituitari anterior dan tiroksin yang disekresikan oleh kelenjar tiroid bekerja secara simultan dalam mengontrol pertumbuhan unggas menjelang pubertas. Hormon somatotropik dalam tubuh berfungsi memacu aktivitas sintesa protein, pembentukan kolagen, metabolisme ion, metabolisme lipid, metabolisme karbohidrat dan metabolisme mineral. Tiroksin didalam tubuh berfungsi memacu aktivitas-aktivitas seperti peningkatan konsumsi oksigen, mempercepat denyut nadi, meningkatkan aktivitas metabolisme, meningkatkan cadangan nitrogen, meningkatkan penyediaan dan merangsang pembentukan hormon somatotropik. Meningkatnya hormon somatotropik dan tiroksin tersebut akan menaikkan konsumsi pakan, sehingga pertumbuhan akan lebih cepat. Peningkatan kedua hormon tersebut pada unggas menjelang pubertas dapat mempertinggi nafsu makan, meningkatkan efisiensi penggunaan pakan dan meningkatkan laju metabolisme basal sehingga meningkatkan laju pertumbuhan. Kerja hormon pertumbuhan efektif mulai postnatal dan paling efektif saat ternak mencapai pubertas, karena semakin dewasa tubuh ternak pengaruh hormon pertumbuhan semakin menurun.

Hasil analisis data menunjukkan adanya perbedaan yang sangat nyata $(\mathrm{P}<0,01)$ terhadap bobot akhir, rataan bobot akhir di lantai 1 lebih rendah dibandingkan dengan bobot akhir di lantai 3. Hal tersebut menunjukkan bahwa bobot akhir di lantai 3 lebih baik dibandingkan bobot akhir di lantai 1 .

\section{Feed Conversion Ratio (FCR) ayam pedaging yang dipelihara pada lantai 1 dan 3}

Hasil penelitian menunjukkan bahwa rataan feed conversion ratio 
(FCR) selama masa pembesaran (umur 15 hari hingga 33 hari) pada lantai 1 adalah $1,83 \pm 0,14$, sedangkan pada lantai 3 adalah 1,77 $\pm 0,11$. Hal tersebut berarti bahwa terdapat selisih rataan feed conversion ratio (FCR) sebesar 0,06. Hasil Uji-t menunjukkan bahwa feed conversion ratio ayam pedaging berbeda sangat nyata $(\mathrm{P}<0,01)$ antara lantai 1 dan lantai 3. Konsumsi pakan dan pertambahan bobot badan berkaitan erat dengan konversi pakan. Konversi pakan merupakan suatu ukuran yang dapat digunakan untuk menilai efisiensi penggunaan pakan dengan menghitung perbandingan antara jumlah pakan yang dikonsumsi dengan pertambahan bobot badan dalam jangka waktu tertentu.

Menurut Sugito dkk. (2007), kondisi lingkungan kandang yang panas dan lembab menyebabkan cekaman panas yang berpengaruh kurang baik pada ternak karena menurunkan pertumbuhan dan efisiensi penggunaan pakan pada ayam pedaging. Suhu dan lingkungan didalam kandang berpengaruh terhadap penampilan produksi ayam pedaging. Griffin et al. (2005) menyatakan bahwa suhu udara ideal untuk pemeliharaan ayam pedaging adalah $10-22{ }^{\circ} \mathrm{C}$ untuk pencapaian berat badan optimum. Program pemberian pakan dengan cara mengatur waktu tertentu merupakan metode yang dapat meningkatkan efisiensi pakan. Hal ini ditunjukkan dengan semakin rendahnya angka konversi pakan, karena aktivitas makan ayam akan berkurang sehingga energi yang diperlukan untuk melakukan aktifitas tersebut dapat dihemat sehingga energi tersebut dapat digunakan untuk pertumbuhan (Muharlien dan Kurniawan 2010). Faktor penyebab tingginya nilai FCR adalah pemberian pakan berlebihan, tempat pakan yang tidak memenuhi standar, sehingga banyak pakan yang tercecer, ayam terserang penyakit, terutama terjangkit penyakit saluran pernapasan sehingga nafsu makan menurun, kandungan gas amonia didalam kandang tinggi, suhu dalam kandang tinggi, serta mutu pakan kurang baik (Subkhie, dkk. 2012). Perbaikan konversi pakan mempunyai arti penting karena berkaitan dengan efisiensi biaya produksi. Nilai konversi pakan yang tinggi menunjukkan bahwa efisiensi pakan kurang baik, sebaliknya nilai konversi pakan yang rendah menunjukkan bahwa makin banyak pakan yang dimanfaatkan oleh ternak (Aryanti, dkk. 2013). Daud (2005) menyatakan semakin tinggi nilai konversi pakan menunjukkan semakin banyak pakan yang dibutuhkan untuk meningkatkan bobot badan persatuan berat. Demikian juga sebaliknya semakin rendah nilai konversi pakan berarti kualitas pakan semakin baik.

Hasil analisis data menunjukkan adanya perbedaan yang sangat nyata $(\mathrm{P}<0,01)$ terhadap feed conversion ratio, rataan feed conversion ratio di lantai 1 lebih tinggi dibandingkan dengan feed conversion ratio di lantai 3 . Hal tersebut menunjukkan bahwa feed conversion ratio di lantai 3 lebih baik dibandingkan feed conversion ratio di lantai 1.

\section{KESIMPULAN}

Hasil penelitian ini menyimpulkan bahwa penampilan produksi ayam pedaging yang dipelihara pada lantai 3 lebih baik dibandingkan pada lantai 1 dengan indikator konsumsi dan konversi pakan pada lantai 3 lebih rendah dibandingkan pada lantai 1. Pertambahan bobot badan, dan bobot akhir pada lantai 3 lebih tinggi dibandingkan pada lantai 1.

\section{DAFTAR PUSTAKA}

Amrullah, L. K. 2003. Nutrisi ayam broiler. Cetakan ke-2. Lembaga Satu Gunung Budi. Bogor. 
Aryanti, F., M. B. Aji, dan N. Budiono. 2013. Pengaruh pemberian gula merah terhadap peforma ayam kampung pedaging. Jurnal veteriner 31(2): 156-164.

Bidura dan Suasta. 2006. Penampilan ayam kampung umur 0-8 minggu yang diberi tepung hipofisa kambing melalui ransum. Majalah Ilmiah Peternakan Denpasar Universitas Udayana 9 (1): 1-10

Daud, M. 2005. Peforman ayam pedaging yang diberi probiotik dan prebiotik dalam ransum. Jurnal Ilmu Ternak 5(2): 75-79.

Faiq, U., N. Iriyanti, dan Roesdiyanto. 2013. Penggunaan pakan fungsional dalam ransum terhadap konsumsi pakan dan pertambahan bobot badan ayam broiler. Jurnal Ilmiah Peternakan 1(1): 282-288.

Griffin, A. M., R. A. Renemar, F. E. Robinson, and M. J. Zuidhof, 2005. The influence of rearing light period and the use of broiler or broiler breeder diets on forty two day body weight, fleshing, and flock uniformity in broiler stocks. Journal of Applied Poultry Research 14(2): 204-216.

Indarto, P. 1999. Dasar-dasar ternak unggas. UB Press. Malang.

Kusnadi, E. 2006. Suplementasi vitamin C sebagai penangkal cekaman panas pada ayam broiler. Jurnal Ilmu Ternak Veteriner 11(4): 249-253.

Kusnadi, E., R. Widjajakusuma, T. Sutardi, P. S. Hardjosworo, dan A. Habibie. 2006. Pemberian antanan (Cantella asiatica) dan vitamin $C$ sebagai upaya mengatasi efek cekaman panas pada broiler. Media Peternakan 29(3): 133-140.
Leeson S. and J. D. Summers. 2000. Commercial poultry nutrition. 3rd Ed. University Books, Canada.

Muharlien, A. dan A. Kurniawan. 2010. Efek lama waktu pembatasan pemberian pakan terhadap performans ayam pedaging finisher. Jurnal Ternak Tropika 11 (2): 88-94.

Nadzir., A. Tusi, A. Haryanto. 2015. Evaluasi desain kandang ayam broiler di desa Rejobinangun, Kecamatan Raman Utara, Kabupaten Lampung Timur. Jurnal Teknik Pertanian Lampung 4(4): 255-266.

Negoro, A. S. P., Achmanu, dan Muharlien. 2013. Pengaruh penggunaan tepung kemanggi dalam pakan terhadap penampilan produksi ayam pedaging. Fakultas Peternakan. Universitas Brawijaya. Malang.

North, M. O., and D. D. Bell. 2004. Commercial chicken production manual. 4th Ed. An Avi Publish. New York.

Nova, K. 2008. Pengaruh perbedaan persentase pemberian pakan antara siang dan malam hari terhadap performa broiler strain $C P$ 707. Animal Production 10: 117121.

Nuriyasa, I. M., E. Puspani, dan I. G. N. Sumatra. 2010. Peningkatan efisiensi produksi ayam petelur melalui peningkatan kenyamanan kandang di Desa Bolangan. ISSN 1412-0925 Udayana mengabdi 9(2): 55-58.

Olivia, M., M. Hartono, dan V. Wanniatie. 2015. Pengaruh jenis bahan litter terhadap gambaran darah broiler yang dipelihara di closed house. Jurnal Ilmiah Peternakan Terpadu 3(1): 23-28. 
Pattiselano, F. dan S. Y. Randa. 2005. Efek frekuensi penaburan zeolit pada alas litter terhadap kualitas lingkungan kandang ayam pedaging. Animal Production 7(2): 89-94.

Puspani, E., I. M. Nuriyasa, W. A. A. P. Putra, dan D. P. M. A. Candrawati. 2008. Pengaruh tipe lantai kandang dan kepadatan ternak terhadap tabiat makan ayam pedaging umur 2-6 minggu. Majalah Ilmiah Peternakan 11(1): 7-11.

Ramadhani, R. A., H. S. Prayogi, dan N. Cholis. 2016. Korelasi antara tingkat deplesi terhadap bobot panen, pertambahan bobot badan, konsumsi pakan, dan FCR pada ayam pedaging. Fakultas Peternakan. Universitas Brawijaya. Malang.

Risnajati, D. 2012. Perbandingan bobot akhir, bobot karkas dan persentase karkas berbagai strain ayam pedaging. Sains Peternakan 10 (1): $11-14$.

Sarjana, T. A. 2007. Manajemen ternak unggas. UNDIP Press. Semarang.

Suarjaya dan M. Nuriyasa. 2010. Penggaruh ketinggian tempat (altitude) dan tingkat energi ransum terhadap penampilan ayam buras super umur 2-7 minggu. Jurnal Fakultas Peternakan. Universitas Udayana. Denpasar.

Subkhie, H., Suryahadi., dan A. Saleh. 2012. Analisis kelayakan usaha peternakan ayam pedaging dengan pola kemitraan di Keca- matan Ciampea Kabupaten Bogor. Manajemen IKM 7(1): 5463.

Sulistyoningsih, M., D. Sunarti, E. Suprijatna, dan Isroli. 2012. Pengaruh pencahayaan terhadap bobot badan, persentase karkas, bobot non-karkas, dan lemak abdominal pada ayam kampung. FPMIPA IKIP PGRI Semarang: 1-15.

Sugito. 2008. Respon pemberian ekstrak n-heksan tanaman jaloh pada ayam broiler yang diberi cekaman panas terhadap ekspresi enzim iNOS pada jaringan paru, kadar glukosa dan kalsium dalam serum. Jurnal Ilmu Ternak Veteriner 13(3): 174-181.

Sugito., W. Manalu, D. A. Astuti, E. Handharyani, dan Chairul. 2007. Morfometrik usus dan peforma ayam broiler yang diberi cekaman panas dan ekstrak nheksana kulit batang jaloh (Salix tetrasperma Roxb). Media Peternakan 30(3): 198-206.

Umam, M. K., H. S. Prayogi, dan V. M. A. Nurgiartiningsih. 2015. Penampilan produksi ayam pedaging yang dipelihara pada sistem lantai kandang panggung dan kandang bertingkat. Jurnal IlmuIlmu Peternakan 24(3): 79-87.

Yunike, T., S. Suharyati, dan K. Nova. 2011. Respon fisiologis ayam jantan tipe medium di kandang panggung dengan kepadatan berbeda. Jurnal Fakultas Pertanian Lampung: 56-60. 